\title{
Expression of c-erbB-2, p53 and c-myc proteins in male breast carcinoma. Comparison with traditional prognostic factors and survival
}

\section{Mourão Netto' ${ }^{1}$ A.F. Logullo², S. Nonogaki ${ }^{3}$, R.R. Brentani ${ }^{4}$ and M.M. Brentani²}

\author{
${ }^{1}$ Hospital do Câncer A.C. Camargo, ${ }^{2}$ D isciplina de O ncologia (LIM-24), \\ Departamento de Radiologia, Faculdade de Medicina, \\ Universidade de São Paulo, Instituto Adolpho Lutz, and \\ ${ }^{4}$ Instituto Ludwig de Pesquisa sobre o Câncer, São Paulo, SP, Brasil
}

\section{Correspondence \\ M.M. Brentani \\ Disciplina de Oncologia \\ Departamento de Radiologia \\ Faculdade de Medicina, USP \\ Av. Dr. Arnaldo, 455 \\ 40 andar, Sala 4112 \\ 01246-903 São Paulo, SP \\ Brasil \\ Fax: + 55-11-282-6580 \\ E-mail: mariajo@ lim24.usp.br \\ Research supported by FAPESP (No. 95/0537-4).}

Received September 27, 2000 Accepted April 4, 2001

\section{Abstract}

There are few data evaluating biological markers for men with breast cancer. The purpose of the present study was to analyze the expression of the oncogenes $c-e r b B-2$ and $c-m y c$ and of the suppressor gene $p 53$ by immunohistochemical techniques in archival paraffin-embedded tissue blocks of 48 male breast cancer patients, treated at the A.C. Camargo Cancer Hospital, São Paulo, SP, Brazil. The results were compared with clinicopathological prognostic features. Immunopositivity of $c$-erbB-2,p53 and $c-m y c$ was detected in $62.5,16.7$ and $20.8 \%$ of the cases analyzed, respectively. Estrogen and progesterone receptors were positive in 75 and $69 \%$ of the cases, respectively. Increasing staging was statistically associated with $c$-erbB-2 $(\mathrm{P}=0.04)$ and weakly related to $p 53$ positivity $(\mathrm{P}=0.06)$. No significant correlation between specific survival rate (determined by the log rank test) and the molecular markers analyzed was found, whereas the number of compromised lymph nodes and advanced TNM (tumor, node, metastasis) staging were associated with diminished survival.

\section{Introduction}

Male breast carcinoma (MBC) is a rare condition representing less than $1 \%$ of breast malignancies. Despite differences in the hormonal milieu, it follows a course of invasion and metastasis similar to that of female breast cancer (1). Several clinicopathological characteristics of male breast carcinoma are considered to be prognostic factors (2-10). Evaluation of the expression of proto-oncogenes, suppressor genes and cell regulatory pro-
Key words - p53

- c-myc

- c-erbB-2

- Male breast cancer 
female breast cancer, i.e., $c$-erbB-2, c-myc and $p 53$. Third, to analyze associations between these features and specific patient survival.

\section{Material and Methods}

\section{Patients}

According to the tumor registry, 102 patients with male breast cancer were diagnosed at the A.C. Camargo Hospital, USP, São Paulo, SP, Brazil, between 1957 and 1998. The clinical files were reviewed and all cases were submitted to a histopathological review of tumor slides in order to confirm diagnosis. Conventional clinicopathological features of each case including tumor size, histologic grade and lymph node status were reviewed. All cases were classified according to the TNM (tumor, node, metastasis) classification system (UICC). Histological grade was established according to Elston and Ellis (11). Morphological analysis of the surgical specimen slides and paraffin-embedded blocks showed that only 48 cases had adequate tumor samples and the most representative sample of each tumor was submitted to immunohistochemical analysis.

\section{Immunohistochemical methods}

Antigens c-myc, p53, c-erbB-2, estrogen (ER) and progesterone receptors (PR) were assessed with the following antibodies: mouse $c$-myc antibody (9E10; Oncogene Science Inc., Manhasset, NY, USA), p53 antibody (DO-7), anti-human c-erbB-2 oncoprotein and ER $\left(\mathrm{ID}_{5}\right.$; Dako A/S, Glostrup, Denmark), and PR (1A6; Novocastra, Newcastle upon Tyne, UK). Positive and negative control slides were used in all reactions. We used previously known female breast cancer cases as positive controls. Negative controls were performed by incubating slides with PBS instead of primary antibody.
Briefly, after deparaffinization in xylol and alcohol, slides ( $3 \mu \mathrm{m}$ thick) were immersed in PBS, pH 7.4, for 5 min and submitted to microwave treatment for epitope retrieval with citric acid solution, $\mathrm{pH} 6.0$, with two 9-min cycles. The material was submitted to endogenous peroxidase blocking treatment $\left(10\right.$ vol. $\left.\mathrm{H}_{2} \mathrm{O}_{2}\right)$ followed by another PBS immersion, and by overnight incubation in a humid chamber at $4^{\circ} \mathrm{C}$ with the primary antibody at $1 / 50$ dilution for $c$ $m y c, 1 / 150$ for $p 53,1 / 100$ for $c-e r b B-2$ and $E R$ and at $1 / 20$ dilution for PR. Slides were then rinsed in PBS solution and incubated with the biotinylated secondary antibody (1:200 dilution; Dako) for 30 min and again rinsed and incubated with the ancillary antibody (StrepAB complex/HRP Duet, mouse/ rabbit) for another $30 \mathrm{~min}$. The material was developed by immersion in 2,3 diaminobenzidine tetrahydrochloride (DAB, Sigma Chemical Co., St. Louis, MO, USA), 60 $\mathrm{mg} \%+1 \%$ dimethyl sulfoxide at $37^{\circ} \mathrm{C}$ for 5 min and by hematoxylin counterstaining. Positivity was characterized by dark brown staining of nucleus (p53, c-myc, ER and PR) or cell membrane and cytoplasm (c-erbB-2). A case was considered positive if more than $20 \%$ of tumor cells were stained. Sections of female breast cancer with known results for the molecular markers analyzed were included as positive and negative controls.

\section{Statistical analysis}

Fisher's exact test at the $95 \%$ significance level was used to assess the univariate association of clinicopathological characteristics with $p 53, c$-erbB-2 and $c$-myc. The time from the date of surgery to the last contact available (for live patients) or to the date of death was used to calculate the survival rate and the survival curves. Patients who died of causes other than breast cancer were treated as censored observations. The distribution of specific survival was estimated using the Kaplan-Meier method. The 
log rank test was used to determine whether any tumor feature, patient characteristic or molecular marker was significantly associated with specific survival.

\section{Results}

Patient and tumor characteristics for the entire cohort and for patients with adequate tissue are shown in Table 1. No significant differences were observed between groups.

Treatment protocols were slightly heterogeneous due to the large time span. In the group of 48 patients for whom tissue was available, modified radical mastectomy was performed in 22 (46\%), radical mastectomy in $16(33 \%)$ and simple mastectomy in 4 $(8 \%)$. According to the staging during diagnosis, the majority of patients in clinical stage IV (6/8) underwent another type of surgery or received only systemic treatment. The remaining two patients (4\%) with metastasis in the homolateral supraclavicular lymph nodes were submitted to radical mastectomy (Halsted operation). Adjuvant therapy was performed as chemotherapy with cyclophosphamide, methotrexate and 5-fluorouracil (CMF) in 4 patients with stage I or II disease. For 2 other patients (stage I and stage II, respectively) 5-fluorouracil, adriblastine and cyclophosphamide (FAC) were prescribed. Five patients with advanced disease were treated with CMF or FAC. Four patients (stages I and II) received hormonal therapy (tamoxifen). Postoperative adjuvant radiation therapy was administered to 23 patients (clinical stages I, II and III). Orchidectomy was performed in 4 patients to treat metastatic disease.

Regional and axillary lymph nodes were evaluated in 38 patients when lymphadenectomy was performed during surgery. The average number of axillary lymph nodes dissected per patient was 22.9 , with a median number of 22.5. In $16(42.10 \%)$ patients, no neoplastic involvement of lymph nodes was identified. Tumor metastasis in lymph nodes was detected in 22 cases: 10 (26.3\%) showed 1-3 involved nodes, 5 (13.2\%) showed 4 to 10 and $7(18.42 \%)$ showed more than 10.

Expression of $c-e r b B-2, p 53$ and $c-m y c$ was positive (i.e., $\geq 20 \%$ of cells displaying

Table 1. Patient and tumor characteristics.

\begin{tabular}{|c|c|c|}
\hline & $\begin{array}{l}\text { All patients } \\
(\mathrm{N}=102)\end{array}$ & $\begin{array}{l}\text { Patients with available tissue } \\
\qquad(\mathrm{N}=48)\end{array}$ \\
\hline Median age (range) (years) & $60(35-84)$ & $62(35-84)$ \\
\hline \multicolumn{3}{|l|}{ Family history } \\
\hline Positive & $18(17.6 \%)$ & $10(20.8 \%)$ \\
\hline Negative & $52(51.0 \%)$ & $31(64.6 \%)$ \\
\hline Unknown & $32(31.4 \%)$ & $7(14.6 \%)$ \\
\hline \multicolumn{3}{|l|}{ Surgery } \\
\hline Biopsy & $5(5.0 \%)$ & $2(4.2 \%)$ \\
\hline Lumpectomy & $8(7.8 \%)$ & $4(8.3 \%)$ \\
\hline Simple mastectomy & $5(5.7 \%)$ & $4(8.3 \%)$ \\
\hline Modified radical mastectomy & $36(35.3 \%)$ & $22(45.8 \%)$ \\
\hline Radical mastectomy & $48(47.0 \%)$ & $16(33.3 \%)$ \\
\hline \multicolumn{3}{|l|}{ Histological features } \\
\hline \multicolumn{3}{|l|}{ Ductal carcinoma in situ (DCIS) } \\
\hline Papillary & $2(4.0 \%)$ & $1(2.1 \%)$ \\
\hline Paget's disease & $1(1.0 \%)$ & $1(2.1 \%)$ \\
\hline \multicolumn{3}{|l|}{ Invasive ductal carcinoma } \\
\hline Papillary & $6(6.0 \%)$ & $4(8.3 \%)$ \\
\hline Colloid & $2(2.0 \%)$ & $1(2.1 \%)$ \\
\hline Microinvasive & $1(1.0 \%)$ & $1(2.1 \%)$ \\
\hline NOS* & $88(86.0 \%)$ & $40(83.3 \%)$ \\
\hline \multicolumn{3}{|l|}{ Stage } \\
\hline DCIS & $3(3.0 \%)$ & $2(4.2 \%)$ \\
\hline I & $6(6.0 \%)$ & $3(6.0 \%)$ \\
\hline IIA & $10(9.8 \%)$ & $6(13.0 \%)$ \\
\hline IIB & $12(11.8 \%)$ & $8(17.0 \%)$ \\
\hline IIIA & $14(13.7 \%)$ & $3(6.0 \%)$ \\
\hline IIIB & $37(36.3 \%)$ & $18(37.0 \%)$ \\
\hline IV & $20(19.6 \%)$ & $8(17.0 \%)$ \\
\hline \multicolumn{3}{|l|}{ Chemotherapy } \\
\hline Yes & $25(24.5 \%)$ & $11(23.0 \%)$ \\
\hline No & $77(75.5 \%)$ & $37(77.0 \%)$ \\
\hline \multicolumn{3}{|l|}{ Adjuvant hormonal therapy } \\
\hline Yes & $10(9.8 \%)$ & $4(8.3 \%)$ \\
\hline No & $92(90.2 \%)$ & $44(91.7 \%)$ \\
\hline \multicolumn{3}{|l|}{ Adjuvant radiotherapy } \\
\hline Yes & $51(50.0 \%)$ & $23(48.0 \%)$ \\
\hline No & $51(50.0 \%)$ & $25(52.0 \%)$ \\
\hline \multicolumn{3}{|l|}{ Histologic grading (HG) } \\
\hline HG I & $18(17.6 \%)$ & $10(20.8 \%)$ \\
\hline HG II & $62(60.8 \%)$ & $30(62.5 \%)$ \\
\hline HG III & $22(21.6 \%)$ & $8(16.7 \%)$ \\
\hline
\end{tabular}

$*$ NOS $=$ not otherwise specified. 
staining positivity) in 30 (62.5\%), 8 (16.7\%) and $10(20.8 \%)$ of the cases analyzed, respectively. Representative illustrations of the immunostainings performed are presented in Figure 1. A total of $36(75 \%)$ and 33 (68.8\%) of the 48 cases were positive for ER and PR, respectively.

The expression of $c$-erbB-2,c-myc and p53 was analyzed in relation to clinical, pathological and biochemical parameters such as age, stage of disease, lymph node involvement, ER and PR (Table 2). A significant association was found between positive staining for $c$-erb $B-2$ and increased staging $(\mathrm{P}=0.04)$. There was also a trend to a higher proportion of $p 53$-positive tumors in advanced stages of the disease $(\mathrm{P}=0.06)$.
The positive factors ER and $p 53$ showed a trend to interdependence $(\mathrm{P}=0.07)$. The $c$ myc-positive tumors were generally c-erb $B-2$ negative $(\mathrm{P}=0.09)$, whereas no correlation was found between $p 53$ and $c-m y c$ or $p 53$ and $c$-erbB-2.

At the last follow-up (August 1999) 18 patients were alive and only 2 had evidence of disease, 14 had died of cancer, 11 had died of other causes, and 5 had no follow-up information. The mean length of follow-up was $67.5 \pm 58.3$ months. For the 14 patients who died of cancer the specific survival rate was estimated to be $75.8 \%$ at 5 years and $60.8 \%$ at 10 years. The specific survival rate was analyzed according to clinical, pathological, biological and treatment parameters
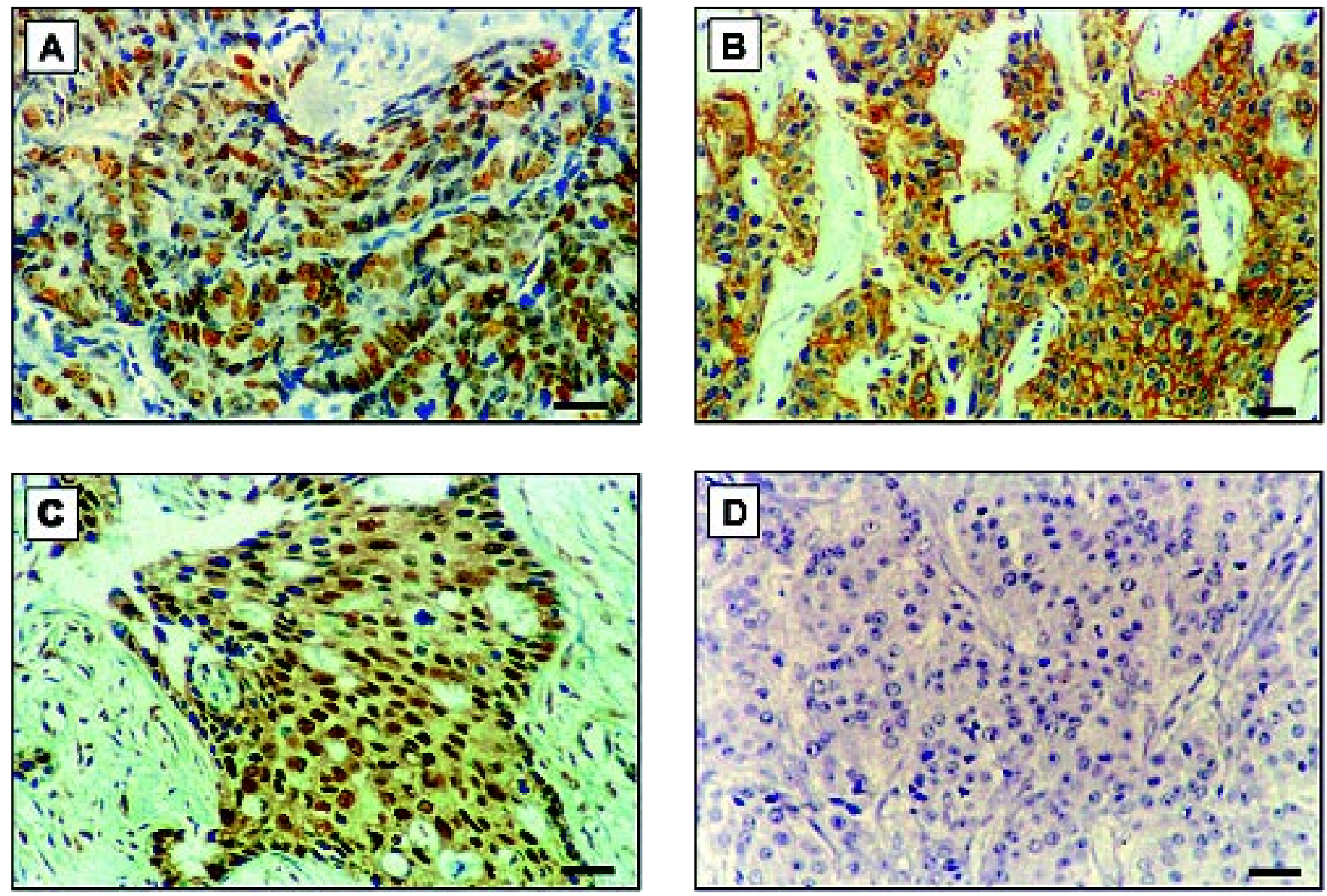

Figure 1. Immunohistochemical detection of p53 (A), c-erbB-2 (B), and c-myc (C) in male breast carcinoma (original magnification 240X). D, Negative control. Bar $=50 \mu \mathrm{m}$. 
(Table 3). Specific survival rates were found to be significantly decreased for patients in more advanced stages of disease and presenting increasing numbers of positive lymph nodes. No significant associations between $c$-erbB-2, $p 53$ or $c$-myc immunohistochemical staining and specific survival probability were observed (Figure 2). Though the analysis did not achieve statistical significance, a worse outcome was found to be correlated with $c$-erbB-2 positivity.

\section{Discussion}

The present report confirms the high median age of MBC patients at the onset of disease, the preponderance of advanced stage tumors and the high incidence of lymph node positivity reported by others. The overall survival rate was also within the range reported in the literature for males (reviewed in 1-3,9,10). Familial breast cancer in males is a noteworthy occurrence. It was recorded
Table 2. Relationship between immunohistochemical features and clinicopathological variables.

\begin{tabular}{|c|c|c|c|c|c|c|c|c|c|}
\hline \multirow[t]{2}{*}{ Variable } & \multicolumn{2}{|c|}{ c-myc } & \multirow[t]{2}{*}{$P$} & \multicolumn{2}{|c|}{ c-erbB-2 } & \multirow[t]{2}{*}{$\mathrm{P}$} & \multicolumn{2}{|c|}{ p53 } & \multirow[t]{2}{*}{$P$} \\
\hline & + & - & & + & - & & + & - & \\
\hline \multicolumn{10}{|l|}{ Age (years) } \\
\hline $35-60$ & 2 & 20 & 0.06 & 15 & 7 & 0.65 & 3 & 19 & 0.60 \\
\hline $61-70$ & 4 & 11 & & 8 & 7 & & 2 & 13 & \\
\hline$>70$ & 4 & 7 & & 7 & 4 & & 3 & 8 & \\
\hline \multicolumn{10}{|l|}{ Stage } \\
\hline DCIS & - & 2 & $0.89 *$ & 1 & 1 & 0.04 & - & 2 & $0.06 *$ \\
\hline 1 & - & 3 & & 1 & 2 & & - & 3 & \\
\hline II & 4 & 10 & & 7 & 7 & & 1 & 13 & \\
\hline III & 4 & 17 & & 14 & 7 & & 3 & 18 & \\
\hline IV & 2 & 6 & & 7 & 1 & & 4 & 4 & \\
\hline \multicolumn{10}{|l|}{ ER status } \\
\hline Positive & 9 & 27 & 0.21 & 23 & 13 & 0.73 & 8 & 28 & 0.07 \\
\hline Negative & 1 & 11 & & 7 & 5 & & 0 & 12 & \\
\hline \multicolumn{10}{|l|}{ PR status } \\
\hline Positive & 8 & 25 & 0.39 & 21 & 12 & 0.81 & 7 & 26 & 0.21 \\
\hline Negative & 2 & 13 & & 9 & 6 & & 1 & 14 & \\
\hline \multicolumn{10}{|c|}{ Number of lymph nodes } \\
\hline Negative & 4 & 12 & 0.57 & 10 & 6 & 0.69 & 3 & 13 & 0.72 \\
\hline $1-3$ & 1 & 9 & & 5 & 5 & & 1 & 9 & \\
\hline $4-10$ & 2 & 3 & & 2 & 3 & & 0 & 5 & \\
\hline$>10$ & 1 & 6 & & 5 & 2 & & 0 & 7 & \\
\hline
\end{tabular}

*Considering clinical stages II, III and IV. Fisher exact test (95\% significance). DCIS, ductal carcinoma in situ; ER, estrogen receptor; PR, progesterone receptor.

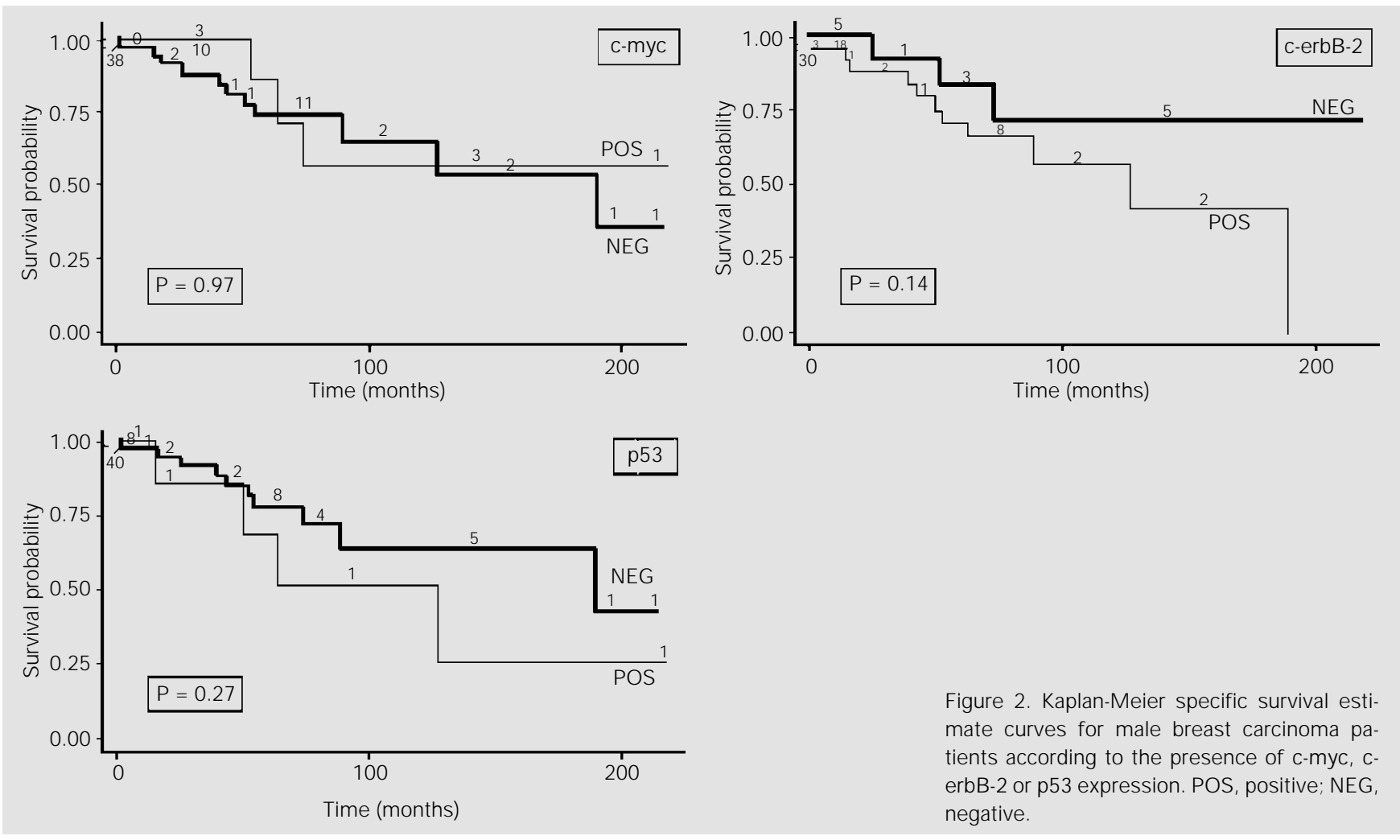


in 18 patients of our series (17.6\%), a value similar to that reported by Salvadori et al. (2). We observed that ER and PR positivity was conspicuously high, in agreement with several previous studies (2-5,12-20).

In female breast cancer, numerous studies have reported $c$-erbB-2 amplification and overexpression and some of them found a positive correlation with earlier relapse and poorer overall patient survival (21). In addi-

\begin{tabular}{|c|c|c|c|c|}
\hline Prognostic variable & $\mathrm{N}$ & $\begin{array}{c}\text { 5-year survival } \\
\text { rate }(\%)\end{array}$ & $\begin{array}{c}\text { 10-year survival } \\
\text { rate }(\%)\end{array}$ & $\mathrm{P}^{*}$ \\
\hline \multicolumn{5}{|c|}{ Number of lymph nodes } \\
\hline Negative & 16 & 88.2 & 88.2 & \multirow[t]{4}{*}{$<0.01$} \\
\hline $1-3$ & 10 & 100.0 & 100.0 & \\
\hline $4-10$ & 5 & 80.0 & 80.0 & \\
\hline$>10$ & 7 & 53.6 & 53.6 & \\
\hline \multicolumn{5}{|l|}{ Stage } \\
\hline DCIS & 2 & 100.0 & 100.0 & \multirow[t]{5}{*}{$<0.01$} \\
\hline 1 & 3 & 100.0 & 100.0 & \\
\hline II & 14 & 100.0 & 100.0 & \\
\hline III & 21 & 71.8 & 48.4 & \\
\hline IV & 8 & 35.7 & 17.9 & \\
\hline \multicolumn{5}{|l|}{ c-myc } \\
\hline Positive & 10 & 85.7 & 53.6 & \multirow[t]{2}{*}{0.97} \\
\hline Negative & 38 & 73.5 & 54.0 & \\
\hline \multicolumn{5}{|l|}{ c-erbB-2 } \\
\hline Positive & 30 & 71.5 & 42.0 & \multirow[t]{2}{*}{0.14} \\
\hline Negative & 18 & 83.5 & 69.6 & \\
\hline \multicolumn{5}{|l|}{ p53 } \\
\hline Positive & 8 & 67.7 & 25.4 & \multirow[t]{2}{*}{0.27} \\
\hline Negative & 40 & 77.5 & 62.7 & \\
\hline \multicolumn{5}{|l|}{ ER } \\
\hline Positive & 36 & 72.9 & 59.6 & \multirow[t]{2}{*}{0.29} \\
\hline Negative & 12 & 82.5 & 66.0 & \\
\hline \multicolumn{5}{|l|}{ PR } \\
\hline Positive & 33 & 78.6 & 61.3 & \multirow[t]{2}{*}{0.90} \\
\hline Negative & 15 & 66.0 & 66.0 & \\
\hline \multicolumn{5}{|l|}{ Radiotherapy } \\
\hline Yes & 23 & 84.0 & 67.0 & \multirow[t]{2}{*}{0.14} \\
\hline No & 25 & 67.0 & 54.0 & \\
\hline \multicolumn{5}{|l|}{ Chemotherapy } \\
\hline Yes & 11 & 78.0 & 63.0 & \multirow[t]{2}{*}{0.88} \\
\hline No & 37 & 75.0 & 56.0 & \\
\hline
\end{tabular}

*Log rank test with significance of $95 \%$.

DCIS, ductal carcinoma in situ; ER, estrogen receptor; PR, progesterone receptor. tion, experimental approaches have provided evidence that the $c$-erbB-2 oncogene plays an important role in cancer metastasis (22). Data available for $\mathrm{MBC}$ indicate a wide range of positivity of $0-95 \%(8,12,16,19,20$, 23-28). We found a high proportion of $c$ erbB-2 positivity (62.5\%) which probably reflects the high number of patients with advanced stage at presentation, since we have verified in our series an association between $c$-erbB-2 and more advanced stage of the disease $(\mathrm{P}=0.04)$. The results of studies that have evaluated the prognostic importance of $c$-erbB-2 in MBC have been contradictory. Some reports indicated a correlation between $c$-erbB-2 and a poorer outcome (10), which could not be established in other studies $(14,19,20,26,27)$. We found only a slight positive correlation between $c$ erbB-2 positivity and specific survival probability $(\mathrm{P}=0.14)$; however, this may have resulted from a small sample size.

Immunohistochemical detection of $p 53$ has been obtained in a low percentage of male breast tumors $(8,12,17,20,28-30)$. Our result $(16.7 \%)$ is within the range previously reported. Although some studies indicated a correlation between $p 53$ and a poorer prognosis $(27,28)$, no such statistical correlation could be established in the current study, in agreement with other reports $(4,12,16,19,20)$. However, we determined a trend to a higher proportion of $p 53$-positive tumors in advanced stages $(\mathrm{P}=0.09)$.

$c-m y c$ is a key cellular proliferative signal in breast tumorigenesis (31). c-myc amplification or overexpression has been reported in female breast tumors but the prognostic significance remains controversial, partly because of discrepancies among different methodologies used for the detection of oncogene amplification or overexpression. The reported frequency of $c-m y c$ overexpression is as high as $100 \%$ in some studies and as low as $12 \%$ in others (reviewed in 32 ). We found that only $20 \%$ of MBC tumor specimens analyzed expressed $c-m y c$ and 
the $c$-myc-positive tumors generally were $c$ erbB-2 negative. Similarly, the simultaneous overexpression of $c$-myc and $c$-er $b B-2$ seems to occur at a very small percentage in female breast cancer (33). Deregulated expression of $c-m y c$ and loss of wild-type $p 53$ function may cooperate in tumor development (34). In our series the co-expression of $c-m y c$ and p53 occurred in $7 \%$ of MBC specimens, but the small number of patients in this category precluded the analysis of association with outcome. Recently, patients with mutations of the $p 53$ gene showed a predisposition for a shorter survival in MBC (29). Many of the sections in the present study were far from optimum because they were prepared from old archival tissue with variations in tissue fixation, hampering this sort of analysis.

The current study evaluated the prognostic significance of $c$-erbB-2,p53 and c-myc in 48 cases of MBC and verified that such biological markers have no statistically sig- nificant correlation with specific overall survival. The present study confirms the importance of staging and axillary lymph node status in the prognosis of male breast cancer patients $(2,3,5-7)$. Our series covers a period of 41 years during which the therapies applied to a small portions of patients have changed, and no firm conclusions can be drawn about the impact of adjuvant treatments on survival. The small number of patients studied precluded multivariate analysis of the data. However, due to the rarity of $\mathrm{MBC}$, reports from single institution series, although including small numbers of patients, will contribute to the advancement of our understanding of this disease.

\section{Acknowledgments}

The authors would like to thank Ms. I.N. Nishimoto for assistance with the statistical analysis.

\section{References}

1. Ravandi-Kashani F \& Hayes TG (1991). Male breast cancer: a review of the literature. European J ournal of Cancer, 34: 1341-1347.

2. Salvadori B, Saccozi R, Manzari A, Andreola S, Conti RA, Cusumano F \& Grassi $M$ (1994). Prognosis of breast cancer in males: an analysis of 170 cases. European J ournal of Cancer, 30: 930-935.

3. Cutuli B, Lacroze M, Dilhuydy J M, Velten $M$, De Lafontan B, Marchal C, Resbeut $M$, Graic Y, Campana F, Moncho-Bernier V, De Gilslain C, Tortochaux J, Cuillere J C, Reme-Saumon M, N'Guyen TD, Lesaunier F, Le Simple T, Gamelin E, Hery M \& Berlie J (1995). Male breast cancer: results of the treatments and prognostic factors in 397 cases. European J ournal of Cancer, 31: 1960-1964.

4. Willsher PC, Leach IH, Ellis IO, Bell J A, Elston CW, Bourke JB, Blamey RW \& Robertson J F (1997). Male breast cancer: pathological and immunohistochemical features. Anticancer Research, 7: 23352338.

5. Donegan WL, Redlich PN, Ang PJ \& Gall
MT (1998). Carcinoma of the breast in males; a multi-institutional survey. Cancer, 83: 498-509.

6. Yildrim E \& Berberoglu U (1998). Male breast cancer: a 22-year experience. European J ournal of Surgical Oncology, 24: 548-552.

7. Vetto J, J un S-Y, Padduch D, Eppich $\mathrm{H}$, Shih R \& Oregon P (1999). Stages at presentation, prognostic factors, and outcome of breast cancer in males. American J ournal of Surgery, 177: 380-383.

8. Wick MR, Sayadi H, Ritter JH, Hill DA, Reddy VB \& Gattuso P (1999). Low-stage carcinoma of the male breast. A histologic, immunohistochemical and flow cytometric comparison with localized female breast carcinoma. American J ournal of Clinical Pathology, 111: 59-69.

9. Borgen PI, Wong GY, Vlamis V, Potter C, Hoffman B, Kinne DW, Osborne MP \& McKinnon WMP (1992). Current management of male breast cancer. A review of 104 cases. Annals of Surgery, 215: 451459.

10. Ginee VF, Olsson H, Moller T, Shallenber- ger RC, van den BlinkJ W, Peter Z, Durand $M$, Dische S, Cleton FJ , Zewuster R, Cui MF, Lane W \& Richter R (1993). The prognosis of breast cancer in males. A report of 335 cases. Cancer, 71: 154-161.

11. Elston CW \& Ellis IO (1991). Pathological prognostic factors in breast cancer. 1 . The value of histological grade in breast cancer. Experience from a large study with long term follow-up. Histopathology, 19: 403-420.

12. J oshi MG, Lee AK, Loda M, Camus MG, Pedersen C, Heatley GJ \& Hughes KS (1996). Male breast carcinoma: an evaluation of prognosis factors contributing to a poorer outcome. Cancer, 77: 490-498.

13. Gupta N, Conhen J L, Rosenbaum C \& Raam S (1974). Estrogen receptors in male breast cancer. Cancer, 46: 17811784.

14. Stalsberg $\mathrm{H}$, Thomas $\mathrm{DB}$, Rosenblatt $K A$, $J$ iminez LM, McTierman A, Stemhagen A, Thompson WD, Curnen MG, Satariano W \& Austin DF (1993). Histologic types and hormone receptors in breast cancer in United States men: a population-based 
study in 282 men. Cancer Causes and Control, 4: 143-151.

15. Sandler B, Carman C \& Perry RR (1994). Cancer of the male breast. American Surgery, 60: 816-820.

16. Bruce DM, Heys SD, Payne S, Miller ID \& Eremin O (1996). Male breast cancer: clinical-pathological features, immunocytochemical characteristics and prognosis. European J ournal of Surgical Oncology, 22: 42-46.

17. Weber-Chappuis K, Bieri-Burger S \& Hurlimann J (1996). Comparison of prognostic markers detected by immunohistochemistry in male and female breast carcinomas. European J ournal of Cancer, 32: 1686-1692.

18. Munoz de Toro MM, Maffini MV, Kass L \& Luque EH (1998). Proliferative activity and steroid hormone receptor status in male breast carcinoma. J ournal of Steroid Biochemistry and Molecular Biology, 67: 333-339.

19. Rayson D, Erlichman C, Suman VJ , Roche PC, Wold LE, Ingle J N \& Donohue JH (1998). Molecular markers in male breast carcinoma. Cancer, 83: 1947-1955.

20. Clark J L, Nguyen PL, J aszcz WB, J atoi A $\&$ Niehans GA (2000). Prognostic variables in male breast cancer. American Surgery, 66: 502-511.

21. Révillion F, Bonneterre J \& Peyrat JP (1998). ErbB-2 oncogene in human breast cancer and its clinical significance. Euro- pean J ournal of Cancer, 34: 791-808.

22. Roetger $A$, Merschjann A, Dittmar $T$, Jackisch C, Barnekow A \& Brandt B (1998). Selection of potentially metastatic subpopulations expressing c-erbB-2 from breast cancer tissue by use of an extravasation model. American J ournal of Pathology, 153: 1797-1806.

23. Fox SB, Day CA \& Rogers S (1991). Lack of c-erbB-2 oncoprotein expression in male breast carcinoma. J ournal of Clinical Pathology, 44: 960-961.

24. Leach IH, Ellis IO \& Elston CW (1992). CerbB-2 expression in male breast carcinoma. J ournal of Clinical Pathology, 45: 942 (Abstract).

25. Lee AK, Wiley B, Loda M, Bosari S, Dugan J M, Hamilton W, Heatley GJ , Cook L \& Silverman ML (1992). DNA ploidy, proliferation and neu-oncogene protein overexpression in breast carcinoma. Modern Pathology, 5: 61-67.

26. Dawson PJ, Paine TM \& Wolman SR (1992). Immunocytochemical characterization of male breast cancer. Modern Pathology, 9: 621-625.

27. Blin N, Kardas I, Welter C, Rys J, Niezabitowski A, Limon J \& Seitz G (1993). Expression of the c-erbB-2 protooncogene in male breast carcinoma: Lack of prognostic significance. Oncology, 50: 408-411.

28. Shpitz B, Bomstein $Y$, Sternberg A, Klein E, Liverant S, Groisman G \& Bernheim J
(2000). Angiogenesis, p53, and c-erbB-2 immunoreactivity and clinicopathological features in male breast cancer. J ournal of Surgical Oncology, 75: 252-257.

29. Anelli A, Anelli TFM, Youngson B, Rosen PP \& Borgen PI (1995). Mutations of the p53 gene in male breast cancer. Cancer, 75: 2233-2238.

30. Pich A, Margaria E, Chiusa L, Ponti R \& Geuna M (1996). DNA ploidy and p53 expression correlate with survival and cell proliferative activity in male breast carcinoma. Human Pathology, 27: 676-682.

31. Bieche I, Laurendeau I, Tozlu S, Olivi M, Vidaud D, Lidereau R \& Videreaud $M$ (1999). Quantification of myc gene expression in sporadic breast tumors with a real-time reverse transcription-PCR assay. Cancer Research, 59: 2270-2275.

32. Nass SJ \& Dickson RB (1997). Defining a role for c-myc breast tumorigenesis. Breast Cancer Research and Treatment, 44: 1-22.

33. Oshima CTF, Nagai MA, Marques LA \& Brentani MM (1995). Analysis of c-myc mRNA expression in primary breast carcinomas with clinical follow-up. International J ournal of Oncology, 6: 719-723.

34. Hermecking $H$, Funk J $O$, Reichert $M$, Ellwart J W \& Eick D (1995). Abrogation of p53-induced cell cycle arrest by c-myc: evidence for an inhibitor of p21 WAF/ CIP1/SDI1. Oncogene, 11: 1409-1415. 